\title{
ABSENCE OF DOSAGE COMPENSATION FOR A SEX-LINKED ENZYME IN BUTTERFLIES (HELICONIUS)*
}

\author{
MICHAEL S. JOHNSON† and JOHN R. G. TURNER $₫$ \\ †Department of Zoology, University of Western Australia, Nedlands, Western Australia 6009, \\ Australia; ¥Department of Ecology and Evolution, State University of New York, Stony Brook, \\ New York 11794, U.S.A.
}

Received 5.iii.79

\begin{abstract}
SUMMARY
6-phosphogluconate dehydrogenase (6PGD) is sex-linked in Heliconius butterflies. Within each of two species tested, the specific activity of 6PGD in males (the homogametic sex) is approximately twice that in females. This confirms that sex-linked genes in lepidoptera, as in birds, are not dosage-compensated. This absence of dosage compensation may be the basis for the frequent femalelimitation of mimicry, and explains the peculiarity that the loci involved are never sex-linked, whereas male-limited sexual characters can be both sex-linked and autosomal.
\end{abstract}

\section{INTRODUGTION}

THE heterogametic sex has only half as many copies of each X-linked gene as has the homogametic sex of the same species. This difference in gene dosage is "compensated" in mammals and in Drosophila, so that males and females produce equal amounts of enzymes from such sex-linked genes. In male Drosophila compensation is achieved by transcription of X-linked genes at twice the female rate (Lucchesi, 1973); in mammals, one of the $\mathrm{X}$-chromosomes in every somatic cell of the female is inactivated, so that females have the same effective gene dose as males (Lyon, 1972). Neither of these mechanisms has been demonstrated to occur in other organisms.

Indeed, dosage compensation itself is not universal. Cock (1964) cited several examples of the absence of dosage compensation in birds, along with two possible such cases in moths. There was apparently no compensation for a sex-linked gene for melanism in the moth Lymantria monacha (Goldschmidt, 1921), but this observation was hard to interpret, as there were indications that the two sexes differed in their general sensitivity to melanisation. Less equivocal was Stehr's (1959) interpretation of haemolymph colours in Choristoneura species as resulting from the interaction of an autosomal locus and a sex-linked modifier locus without dosage compensation, which he extended to account for the wide occurrence of sex-limited polymorphism in lepidoptera, thereby implying that the absence of dosage compensation in these organisms is widespread. In this paper we present the first direct evidence for the absence of dosage compensation of a sex-linked locus in lepidoptera.

* Contribution number 247 from the Program in Ecology and Evolution at the State University of New York at Stony Brook.

$\S$ Present address: Department of Genetics, University of Leeds, Leeds LS2 9JT, England. 


\section{MATERials AND METHODS}

Several species of butterflies of the South American genus Heliconius are polymorphic for the enzyme 6-phosphogluconic dehydrogenase (6PGD; E.C. 1.1.1.43), as revealed by starch-gel electrophoresis (Turner et al., 1979). We have confirmed segregation of the 6PGD variants in Heliconius melpomene. Indications of sex-linkage of 6PGD were tested by electrophoresis of laboratory stocks of $H$. melpomene originating from Belém, Brasil, and of wildcaught samples of Heliconius erato from Trinidad and Panamá. Variation in $\alpha$-glycerophosphate dehydrogenase ( $\alpha \mathrm{GPD}$; E.C. 1.1.1.8) was also assessed for the same samples. The enzymes were detected essentially as described by Brewer (1970).

Activities of 6PGD and $\alpha$ GPD were determined for adults from laboratory stocks of $H$. melpomene originating from Belém, and of $H$. erato originating from São Paulo and Rio de Janeiro. Only the head and thorax were used, 20 to $40 \mathrm{mg}$ of tissue (two or three butterflies) being homogenised in $0.1 \mathrm{ml}$ distilled water per $\mathrm{mg}$ tissue. Homogenates were incubated for $20 \mathrm{~min}$. in an ice bath, then centrifuged for $15 \mathrm{~min}$. at $4000 \mathrm{xg}$ to remove debris. For $H$. melpomene, six preparations from males and two preparations from females were made. For $H$. erato, two extracts from females and one from males were made.

The reaction mixture for the 6 PGD assay was $0.05 \mathrm{ml}$ extract, $1 \mathrm{mg}$ NADP, $8 \mathrm{mg}$ sodium 6-phosphogluconate, and $2 \mathrm{mg} \mathrm{MgCl}_{2}$ in $2 \mathrm{ml} 0.1 \mathrm{~m}$ Tris (hydroxymethyl) aminomethane- $\mathrm{HCl}$ buffer, $p \mathrm{H} 8.0$. The reaction mixture for $\alpha \mathrm{GPD}$ was $0.02 \mathrm{ml}$ extract, $10 \mathrm{mg}$ sodium $\alpha$-glycerophosphate,

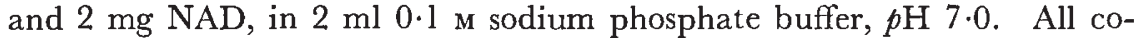
factors and substrates were from Sigma Chemical Co. (Saint Louis, Missouri).

The reactions were followed as an increase in absorbance at $340 \mathrm{~m} \mu$, using a Beckman DB spectrophotometer. Reaction rates were measured at $25^{\circ} \mathrm{C}$ for $2 \mathrm{~min}$., the rates being linear during this period. In each case, the reference cuvette contained the assay mixture, excluding the substrate. Protein concentrations of the extracts were determined by ultraviolet absorbance (Layne, 1963), and enzyme activities were expressed as $\mu$ moles $\mathrm{NADPH}$ (or $\mathrm{NADH}$ ) converted per min. per mg protein.

TABLE 1

Comparison of numbers of homozygotes and heterozygotes for 6PGD in males and females of Heliconius melpomene and $\mathrm{H}$. erato. Allozymes are labeled alphabetically in decreasing order of electrophoretic mobility

\begin{tabular}{|c|c|c|c|c|c|c|}
\hline \multirow[b]{2}{*}{ H. melpomene } & \multicolumn{3}{|c|}{ Homozygotes } & \multicolumn{3}{|c|}{ Heterozygotes } \\
\hline & & $\mathrm{CG}$ & $\mathrm{DD}$ & $\mathrm{BC}$ & $\mathrm{BD}$ & $\mathrm{CD}$ \\
\hline Males & & 13 & 2 & 5 & 5 & 8 \\
\hline Females & & 15 & 3 & 0 & 0 & 0 \\
\hline H. erato & AA & $\mathrm{CG}$ & $\mathrm{EE}$ & $\mathrm{AG}$ & $\mathrm{AE}$ & \\
\hline Trinidad males & 39 & 27 & 0 & 43 & 3 & \\
\hline females & 29 & 33 & 0 & 0 & 0 & \\
\hline Panamá males & 13 & 9 & 5 & 13 & 2 & \\
\hline females & 18 & 5 & 2 & 0 & 0 & \\
\hline
\end{tabular}




\section{REsults}

6PGD is $\mathrm{X}(\mathrm{Z})$-linked, as shown by the absence of heterozygous females (the heterogametic sex), despite large numbers of heterozygous males in both $H$. melpomene and $H$. erato (table 1). No heterozygous females have been found in any species of Heliconius or the related genus Dryas (table 2), suggesting (although small sample sizes preclude certainty) that 6PGD is $\mathrm{X}$-linked in the whole group. Heterozygotes of each sex were found for $\alpha \mathrm{GPD}$, confirming the autosomal inheritance of this enzyme.

TABLE 2

Comparison of numbers of homozygotes and heterozygotes for 6PGD in males and females of several species of Heliconius and Dryas

\begin{tabular}{lcccc} 
& \multicolumn{3}{c}{ Females } \\
Species & \cline { 2 - 5 } Homozygotes & Heterozygotes & Homozygotes & Heterozygotes \\
H. atthis & 9 & 3 & 3 & 0 \\
$H$. cydno & 3 & 1 & 2 & 0 \\
H. ismenius & 2 & 1 & 5 & 0 \\
H. numata & 15 & 3 & 6 & 0 \\
H. sara & 70 & 2 & 34 & 0 \\
D. iulia & 28 & 2 & 5 & 0 \\
$\quad$ Total & 127 & 12 & 55 & 0
\end{tabular}

In both $H$. melpomene and $H$. erato the specific activity of 6PGD is significantly greater in males than in females (table 3 ). The ratio of activity in females to activity in males in not appreciably different from one half. As there was a possibility of their being general differences in enzyme activities in the two sexes, we also determined activities of the autosomally encoded aGPD. No differences between males and females were found (table 3). Consequently, activities of each enzyme simply reflect gene dosage. As expected in the absence of dosage compensation, the ratio of 6 PGD to $\alpha$ GPD activities is twice as large in males as in females of the same species (Table 3-all probabilities are one-tailed; no heterogeneity of residual variances).

\section{TABLE 3}

Comparison of activities of $6 P G D$ and $\alpha C P D$ in adult males and females of Heliconius melpomene and $\mathrm{H}$. erato. Values are mean \pm standard deviation umoles $\mathcal{N} A D P H$ (or $\mathcal{N} A D H$ ) converted per min. per mg protein

\begin{tabular}{|c|c|c|c|c|c|}
\hline & Males & Females & $\mathrm{t}$ & d.f. & $\mathbf{P}$ \\
\hline \multicolumn{6}{|l|}{ H. melpomene } \\
\hline 6PGD & $3 \cdot 24 \pm 0.80$ & $1 \cdot 32 \pm 0 \cdot 28$ & $3 \cdot 18$ & 6 & 0.0095 \\
\hline$\alpha \mathrm{GPD}$ & $9.88 \pm 1.63$ & $8.61 \pm 0.23$ & $1 \cdot 04$ & 6 & $0 \cdot 17$ \\
\hline $6 \mathrm{PGD} / \alpha \mathrm{GPD}$ & $0.33 \pm 0.05$ & $0.15 \pm 0.03$ & $4 \cdot 90$ & 6 & 0.0014 \\
\hline \multicolumn{6}{|l|}{ H. erato } \\
\hline 6PGD & $7 \cdot 25$ & $3 \cdot 36 \pm 0 \cdot 16$ & $19 \cdot 50$ & 1 & $0.016 *$ \\
\hline$\alpha G P D$ & $10 \cdot 46$ & $9 \cdot 36 \pm 0.31$ & $2 \cdot 89$ & 1 & $0 \cdot 11$ \\
\hline $6 \mathrm{PGD} / \alpha \mathrm{GPD}$ & $0 \cdot 69$ & $0.36 \pm 0.03$ & $9 \cdot 27$ & 1 & 0.034 \\
\hline
\end{tabular}

* Significant 5 per cent; ** Significant 1 per cent 


\section{Discussion}

\section{(i) Evolution of dosage compensation}

The scarcity of information on sex-linked genes has prevented an evaluation of the prevalence of dosage compensation in groups other than mammals, birds (which lack compensation), and Drosophila (Cock, 1964). Indeed, 6PGD in Heliconius is only the third example of an X-linked locus in butterflies (Silberglied and Taylor, 1973; Grula and Taylor, 1979), and only the second X-linked enzyme in a lepidopteran (May, Leonard and Vadas, 1977). The approximately two-fold difference in 6PGD activities of males and females is a clear case of the absence of dosage compensation. While it could be that by chance we have encountered one of the few uncompensated loci in an otherwise compensated $\mathrm{X}$ chromosome, or a locus with sex-limited expression (e.g. Freyvogel et al., 1968) which is, fortuitously, sex-linked, this seems unlikely in view of the evidence for the absence of dosage compensation in Lymantria and Choristoneura (Goldschmidt, 1921; Stehr, 1959).

In some cases, such as the determination of sex, the absence of dosage compensation is to be expected. Similarly, if natural selection favours female-limited colour polymorphism in butterflies (Sheppard, 1961), the absence of dosage compensation could be adaptive (Stehr, 1959). However, the fact that the 6PGD variation in Heliconius does not underlie a visible polymorphism suggests that the absence of dosage compensation in lepidoptera may be general, rather than restricted to genes of special function.

That mechanisms exist for dosage compensation of individual genes or small portions of chromosomes has been shown in Drosophila (Bowman and Simmonds, 1973; Lucchesi, 1973; Strobel et al., 1978). Consequently, our results are counterintuitive: there are no obvious genetic or evolutionary reasons for X-linked genes in general to be uncompensated in lepidoptera. Indeed, from the apparent selective importance of genetic variation in enzyme activities (Koehn, 1969; Merritt, 1972; Day et al., 1974; Miller et al., 1975; McDonald and Avise, 1976; Devonshire, 1977), one would predict either selection for dosage compensation of most sex-linked genes, or selection for translocation of portions of the sex chromosomes to the autosomes.

We do not understand why dosage compensation occurs in some organisms, but not in others. Why, for example, is it necessary for Drosophila males and females to have the same activity of sex-linked enzymes, but not Heliconius? There does appear to be some regularity in the presence or absence of dosage compensation. In both Drosophila and mammals, the two groups known to have dosage compensation, males are the heterogametic sex; in contrast, both lepidoptera and birds, which lack compensation, have heterogametic females, and apparently $\mathrm{Y}(\mathrm{W})$-chromosomes which are inactivated in the somatic tissues (Smith, 1945; Cock, 1964; Clarke et al., 1976).

Charlesworth (1978) has postulated that in evolutionary time, the inactivation of the $\mathrm{Y}$ chromosome is an active process, accompanied in Drosophila and mammals by a compensating increase in the activity of the $\mathrm{X}$ to restore normal gene dosage. Lepidoptera demonstrate the first process very clearly; as is shown by those females of Papilio glaucus which have an active Y chromosome (Clarke et al., 1976), the Y, far from being 
genetically inert has potentially functioning genes (not involved in sex determination or fertility), and is "switched off" in the somatic tissues by being condensed into a heteropycnotic body, like the $\mathrm{X}$ chromosome in mammals. Another curious regularity relates to the fact that it is only females which inactivate chromosomes, whether $\mathrm{X}$ or $\mathrm{Y}$, in this way. It is possible, but unlikely, that lepidoptera inactivate the $Y$ chromosome because there is some adaptive advantage in having a sex-difference in dosage for some of the sex-linked genes. If, on the other hand, the $Y$ is inactivated as Charlesworth suggests, to nullify the effects of accumulated mutational damage, we need to find some explanation for their failure to develop dosage compensation at the same time. The metabolism of the active and inactive $\mathrm{Y}$ females of Papilio glaucus would be of great interest.

\section{(ii) Genetic architecture of sex-limitation in lepidoptera}

If the whole, or most, of the $\mathrm{X}$ chromosome in butterflies lacks dosage compensation, then this probably does provide the metabolic base for the limitation of expression to the female sex, which is a common feature of mimicry, and of some non-mimetic polymorphisms, in butterflies (e.g. Turner, 1978). For an autosomal allele to be sex limited in its expression, it is not necessary that it interact with an X-linked locus with felicitously adjusted dosages, as in Stehr's original model; interaction with the metabolic products of any X-linked locus could provide an opportunity for limiting expression to one sex or the other.

Moreover, it is now possible to answer the question raised by Sheppard (1961); if female-limitation is produced by the interaction of a pair of loci, why do we always find that the alleles controlling the polymorphism are on the autosome? One would expect the polymorphism to be controlled in roughly half the species from the X-linked member of the pair.

Consider an allele at the autosomal locus; for its expression to be limited to females it must interact with the X-linked locus in such a way that a single dose permits, and a double dose suppresses, expression. This seems perfectly feasible. But for an X-linked allele to be female-limited it is necessary that it be expressed in a single dose, but that its interactions with the autosome are somehow arranged that expression should disappear when the dose is doubled in a male. Although such interaction may not be impossible, it is perhaps rather rare, and this would account for our failure to find any female-limited X-linked polymorphisms.

Interestingly enough, this restriction does not apply to male-limitation. An X-linked allele will be male-limited if expressed in a double dose in the $\mathrm{XX}$ male, but not in a single dose in the XY female; an autosomal allele will be so if a single dose from its X-linked partner does not permit expression, which is enhanced to the point of penetrance by a double dose of the X-linked product (the opposite kind of interaction from that required for femalelimitation). As both these styles of gene action seem quite likely, roughly 50 per cent of male-limited characters in butterflies (and just possibly in birds like ducks and pheasants) should turn out to be X-linked. This is exactly what has been found in the only investigation so far made of the repertoire of secondary sexual characters in a male butterfly; on hybridising the closely related species Colias eurytheme and $C$. philodice, it was found that both ultraviolet reflectance and hydrocarbon pheromones (the 
secondary male characters of eurytheme) were X-linked, and that the n-hexyl esters which are the male pheromones of philodice were controlled by autosomal genes (Silberglied and Taylor, 1973; Grula and Taylor, 1979). Thus the linkage of the pheromone and reflectance genes on the $\mathrm{X}$ chromosome is not necessarily evidence for the evolution of a supergene (as suggested by Grula and Taylor, 1979), but is an outcome of Stehr's hypothesis that sex-limitation in lepidoptera results from the interaction of autosomal genes and uncompensated X-linked genes. Female-limited characters will be predominantly autosomal, and of the genes controlling male-limited characters, roughly half will be scattered among the autosomes and the rest will be linked together on the $\mathrm{X}$ chromosome.

Acknowledgments.-We thank Dr R. K. Koehn and Professor S. D. Bradshaw for facilities provided, Dr W. F. Eanes for assistance, and Dr B. Charlesworth and Dr. L. M. Cook for reading the draft. The late Professor P. M. Sheppard, F.R.S., provided the specimens for the determination of enzyme activities. This work was supported by NIH Grant 3R01GM20702 to J.R.G.T. and research funds from the University of Western Australia to M.S.J.

\section{REFERENGES}

Bowman, J. T., ANd simmons, J. R. 1973. Gene modulation in Drosophila: dosage compensation of $\mathrm{Pgd}^{+}$and $\mathrm{Zw}^{+}$genes. Biochemical Genetics, 10, 319-331.

Brewer, G. J. 1970. An Introduction to Isozyme Techniques. Academic Press, New York. CHARLESWORTH, B. 1978. Model for evolution of Y chromosomes and dosage compensation. Proceedings of the National Academy of Sciences, USA, 75, 5618-5622.

CLARKE, C. A., SHEPPARD, P. M., AND MITTWOCH, U. 1976. Heterochromatin polymorphism and colour pattern in the tiger swallowtail butterfly Papilio glaucus L. Nature, 263, 585-587.

соск, A. G. 1964. Dosage compensation and sex-chromatin in non-mammals. Genetical Research, 5, 354-365.

DAY, T. H., Hillier, P. C., AND Clarke, B. 1974. Properties of genetically polymorphic isozymes of alcohol dehydrogenase in Drosophila melanogaster. Biochemical Genetics, 11, 141-153.

DEVONSHIRE, A. L. 1977. The properties of a carboxylesterase from the peach-potato aphid, Myzus persicae (Sulz.), and its role in conferring insecticide resistance. Biochemical Journal, 167, 675-683.

FREYVOGEL, T. A., HUNTER, R. L., AND SMTTH, E. M. 1968. Non-specific esterases in mosquitoes. Journal of Histochemistry and Phytochemistry., 16, 765-789.

GOLDschmidT, R. B. 1921. Erblichskeitstudien an Schmetterlingen III. Der Melanismus der Noune, Lymantria monacha L. Zeitschrift für induktive Abstammungs- und VererbungsLehre, 25, 89-163.

GRULA, J. W., AND TAYLOR, O. R. 1979. The inheritance of pheromone production in the Sulfur butterflies Colias eurytheme and C. philodice. Heredity, 42, 359-371.

ковнN, R. к. 1969. Esterase heterogeneity: dynamics of a polymorphism. Science, 163, 943-944.

LAYNE, E. 1963. Spectrophotometric and turbidimetric methods for measuring proteins. Methods in Enzymology, III, 448-454.

Lucchesr, J. c. 1973. Dosage compensation in Drosophila. Annual Review of Genetics, 7, 225-237.

LYON, M. F. 1972. X-chromosome inactivation and developmental patterns in mammals. Biological Reviews, 47, 1-35.

MCDONALD, J. F., AND Avise, J. G. 1976. Evidence for the adaptive significance of enzyme activity levels: Interspecific variation in $\alpha-\mathrm{GPDH}$ and $\mathrm{ADH}$ in Drosophila. Biochemical Genetics, 14, 347-355.

MAY, B., LEONARD, D. E., AND VADAS, R. L. 1977. Electrophoretic variation and sex linkage in spruce budworm. Fournal of Heredity, 68, 355-359.

MERritT, R. B. 1972. Geographic distribution and enzymatic properties of lactate dehydrogenase allozymes in the fathead minnow, Pimaphales promelas. American Naturalist, 106, 173-184. 
Miller, s., PeArcy, R. W., AND Berger, E. 1975. Polymorphism at the $\alpha$-glycerophosphate dehydrogenase locus in Drosophila melanogaster. I. Properties of adult allozymes. Biochemical Genetics, 13, 175-188.

SHEPPARD, P. M. 1961. Some contributions to population genetics resulting from the study of the Lepidoptera. Advances in Genetics, 10, 165-216.

SILBERGLIED, R. E., AND TAYLOR, O. R. 1973. Ultraviolet differences between the sulphur butterflies, Colias eurytheme and C. philodice, and a possible isolating mechanism. Nature, 241, 406-408.

smrth, s. G. 1945. The diagnosis of sex by means of heteropycnosis. Science in Agriculture, $25,566-571$.

STEHR, G. 1959. Haemolymph polymorphism in a moth and the nature of sex-controlled inheritance. Evolution, 13, 537-560.

STROBEl, E., PELling, C., AND ARNheim, N. 1978. Incomplete dosage compensation in an evolving Drosophila sex chromosome. Proceedings of the National Academy of Sciences, U.S.A., 75, 931-935.

TURNER, J. R. G. 1978. Why male butterflies are non-mimetic: natural selection, sexual selection, group selection, modification and sieving. Biological Journal of the Linnaean Society of London, 10, 385-432.

TURNER, J. R. G., Johnson, M. s., AND EANES, w. F. 1979. Contrasted modes of evolution in the same genome: allozymes and adaptive change in Heliconius. Proceedings of the National Academy of Sciences, USA, 76, 1924-1928. 